\title{
KLEANTES SE HIMNE AAN ZEUS
}

\section{J C Thom (Universiteit van Stellenbosch)}

Kleantes van Assos (ca. 310-230 v.C.) se Himne aan Zeus word allerweë as 'n besondere dokument beskou. Vanuit 'n filosofies-historiese perspektief is dit van groot waarde omdat dit die enigste vroeg-Stoisynse teks van beduidende lengte is wat min of meer in sy geheel behoue gebly het. Van groter interesse is egter die feit dat Kleantes oënskynlik in hierdie himne sy Stoïsyns-filosofiese denke met 'n opregte vroomheid kombineer (Wilamowitz-Moellendorff 1955:2.288). Een geleerde noem die Himne trouens "een van die treffendste oorblyfsels van antieke vroomheid" (Festugière [1949] 1983:311; verdere verwysings in Mansfeld 1979:130-131). Só beskou is die Himne aan Zeus 'n belangrike illustrasie van die wyse waarop filosofie in die Hellenistiese tyd die rol van 'n surrogaat-godsdiens begin vervul het (vgl Festugière [1949] 1983:310-332; 1954:106-112).

Hoewel daar die afgelope eeu 'n aantal uitstekende studies oor die Himne aan Zeus verskyn het, ${ }^{1}$ is daar nogtans 'n paar probleme rakende die komposisie en interpretasie wat nog nie bevredigend opgelos is nie. Hierdie probleme het veral te make met die rol wat die 'slegtes' (v.17) in die gedig speel, Zeus se verhouding tot die kwaad (vv.18-21) en die verband tussen die gebed aan die einde (vv.32-39) en die res van die gedig. In hierdie artikel sal gepoog word om 'n nuwe interpretasie van die gedig te gee wat reg laat geskied aan bogenoemde vraagstukke.

\section{Teks en vertaling}

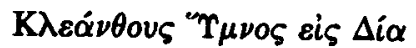

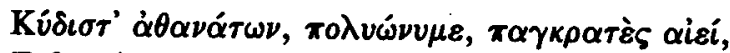

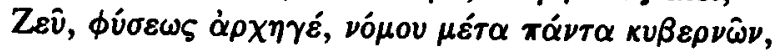

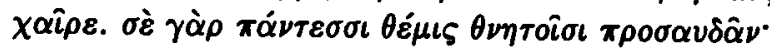

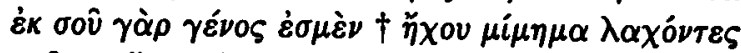

$5 \mu$ กิv

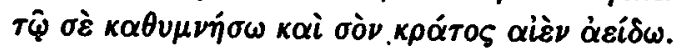

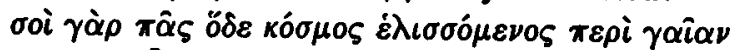

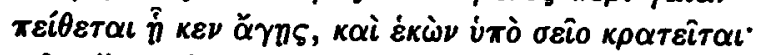

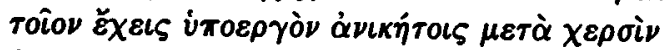

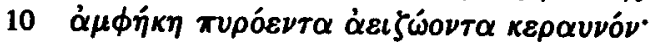

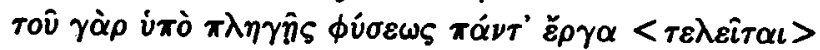

1 Ek noem slegs die belangrikste publikasies wat die gedig as geheel of minstens groot dele daarvan bespreek: Wilamowitz-Moellendorff 1924; 1925:306-332; Adam 1911:104-189; Neustadt 1931; Pohlenz 1940; Festugière [1949] 1983:310-332; Verbeke 1949:235-251; Meerwaldt 1951:58-69; 1952; Zuntz 1958; James 1972; Meijer 1983; Watanabe 1988:156-171; Hopkinson 1988:131-16; Sier 1990. 


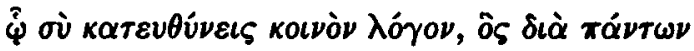

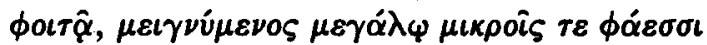

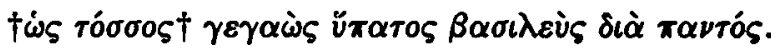

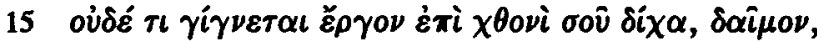

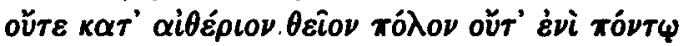

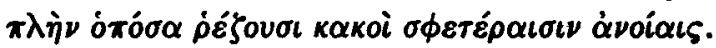

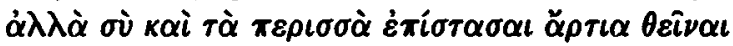

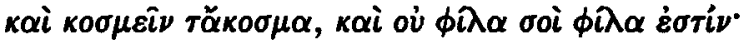

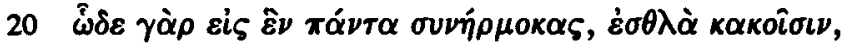

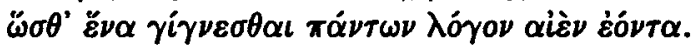

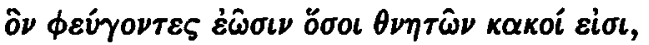

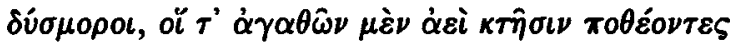

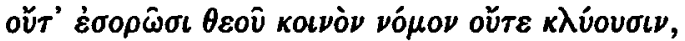

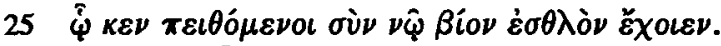

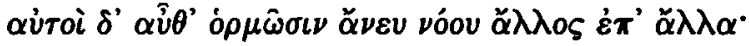

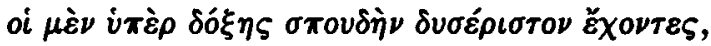

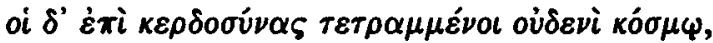

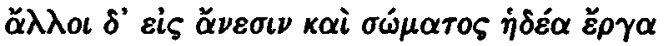

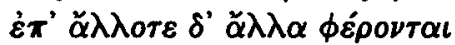

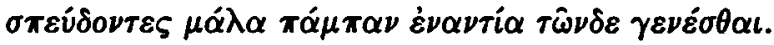
$\dot{\alpha} \lambda \lambda \dot{\alpha} \mathrm{Z} \varepsilon \hat{v} \pi \dot{\alpha} \nu \delta \omega \rho \varepsilon, \kappa \varepsilon \lambda \alpha \iota \nu \varepsilon \phi \varepsilon ́ \varsigma, \dot{\alpha} \rho \chi\llcorner\kappa \varepsilon \dot{\rho} \alpha u \nu \varepsilon$,

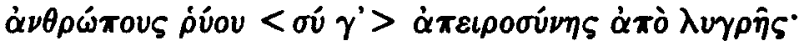

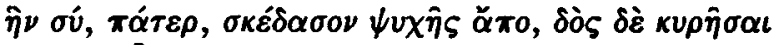

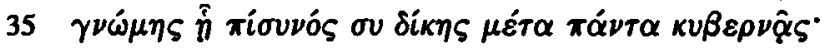
ŏ $\phi \rho^{\prime} \hat{\alpha} \nu \tau \iota \mu \eta \theta \dot{\varepsilon} \nu \tau \varepsilon \zeta \dot{\alpha} \mu \varepsilon \iota \beta \dot{\omega} \mu \varepsilon \sigma \theta \dot{\alpha} \sigma \varepsilon \tau \iota \mu \hat{\eta}$,

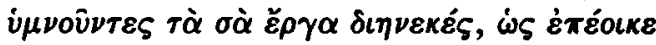

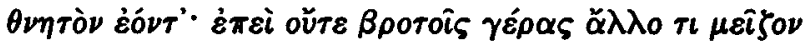

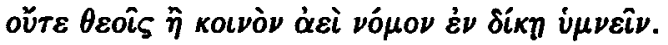

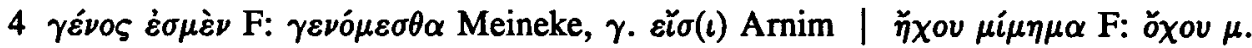

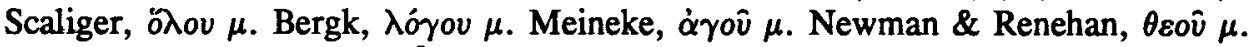

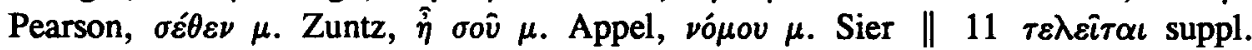
Arnim, $\delta \alpha \mu \alpha \dot{\alpha} \sigma \theta \eta$ Pearson, $\beta \varepsilon \dot{\varepsilon} \eta \kappa \varepsilon \nu$ Powell, $\pi \dot{\varepsilon} \pi \eta \gamma \varepsilon$ Pohlenz, $\tau \dot{\varepsilon} \tau u \kappa \tau \alpha \iota$ Dragona-

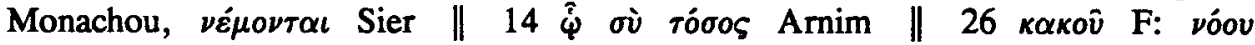

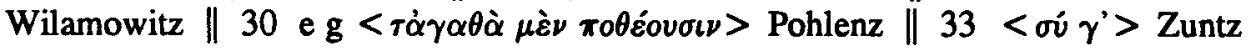

Kleantes se Himne aan Zeus

Edelste van die onsterflikes, veel-namige, altyd almagtige Zeus, hoof en leier van die natuur, wat met $u$ wet alles stuur, gegroet! Dit is mos reg vir alle sterflinge om $u$ aan te spreek. 
Want ons het ons oorsprong in $u$, omdat ons ' $n$ afbeelding van die heelal ${ }^{2}$ verkry het, slegs ons van alle sterflikes wat leef en kruip op aarde.

Daarom sal ek u prys en u mag altyd besing.

Hierdie hele wêreld, terwyl dit om die aarde wentel, gehoorsaam mos vir $u$, waarheen u ookal lei, en word gewilliglik deur $u$ beheer.

So ' $n$ dienaar het $\mathrm{u}$ in $\mathrm{u}$ onoorwinlike hande, die tweesnydende, vurige, altyd-lewendige weerligstraal.

Want deur sy slae word alle werke van die natuur < voltooi $>$.

Daarmee rig u die universele rede wat deur alles dring, terwyl dit met groot en klein hemelligte meng.

Daarom is u so groot, ${ }^{3}$ die hoogste koning vir altyd.

Geen enkele daad op aarde kom tot stand sonder $\mathrm{u}$ nie, God,

ook nie in die goddelike hemelsfeer of in die see nie,

behalwe wat slegte mense in hul dwaasheid verrig.

Maar $u$ weet hoe om die ongelyke gelyk te maak

en om die onordelike te orden; selfs die onbeminlike word deur u bemin.

Want u voeg ${ }^{4}$ só alles tot een saam, die goeie met die slegte,

dat daar vir alles één ewigdurende rasionele orde tot stand kom.

Dít ontvlug en vermy alle sterflinge wat sleg is,

die ellendiges, wat altyd na die verkryging van die goeie begeer,

maar God se universele wet nie sien of hoor nie,

hoewel as hulle dit gehoorsaam, hulle 'n goeie lewe met begrip sou hê.

Maar hulle storm dadelik sonder verstand elkeen agter iets anders aan, sommige met 'n twissoekerige ywer vir roem,

ander ongebreideld gerig op winsbejag,

ander weer op ontspanning en die aangename dade van die liggaam.

$<$ Hulle begeer die goeie > 5 maar word nou na dít, dan weer na dát meegevoer, 30

terwyl hulle ywerig daarna streef dat geheel en al die teenoorgestelde

hiervan gebeur.

Zeus, gewer van alles, wolkbedekte heerser van die weerlig,

red mense van hul vernietigende onvermoë;

verstrooi dit uit hul siel, Vader; gee dat hulle die oordeelsvermoë

bekom waarop u vertrou om alles met geregtigheid te stuur,

sodat ons, geëerd, u op ons beurt kan eer, terwyl ons onophoudelik $u$ werke besing soos dit een betaam wat 'n sterfling is. Want daar is nie vir sterflinge 'n ander groter eer nie, ook nie vir gode nie, as om altyd met reg u universele wet te besing.

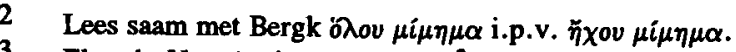

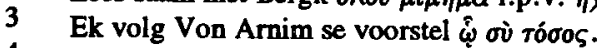

4 Die perfektum word hier emfaties gebruik.

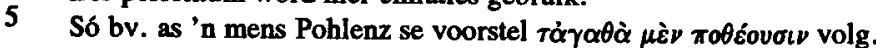


Die Himne aan Zeus is slegs in die vyfde-eeuse bloemlesing deur Stobaios (Anthologium 1.1.12 Wachsmuth) behoue, en wel in net een van die twee basismanuskripte van die Anthologium, nl Neapolitanus Farnesinus III D 15 van die 14de eeu (F). My teks is gebaseer op dié van Zuntz (1958) wat die teks breedvioerig bespreek en ook 'n foto van die manuskrip gee; die tekskritiese apparaat hierbo dui dus slegs enkele van die belangrikste probleme en konjekture aan.

\section{Outeur en datering}

Kleantes is ca. $310 \mathrm{vC}$ in Assos gebore en het in 281 na Atene gekom waar hy in die betreklik rype ouderdom van bykans 30 jaar onder Zeno van Kition begin studeer het. In 262 volg hy Zeno as hoof van die Stoa op, 'n rol wat hy vir 32 jaar tot met sy dood in 230/29 vervul het (Steinmetz 1994:566-567). Verskeie interessante staaltjies word oor hom vertel, o.a. dat hy eers ' $n$ bokser was, dat hy so arm was dat hy hom as student onderhou het deur snags water vir tuine aan te dra en dat sy medestudente hom weens sy stompsinnigheid die skelwoord 'Esel' gegee het, waarop Kleantes geantwoord het dat net hy sterk genoeg is om die las van Zeno se filosofie te dra (Diog. Laert. 7.168-170).

Ongelukkig het ons geen presiese aanduiding wanneer gedurende sy loopbaan hy die Himne aan Zeus geskryf het nie: volgens Wilamowitz (1912:203) was dit reeds as jongman, terwyl Festa (1935:173-174) meen die Himne is die produk van 'n ouer en ryper persoon. Dit is alles egter blote spekulasie.

\section{Genre en funksie}

Die Himne aan Zeus openbaar baie duidelik die tradisionele vorm en motiewe van 'n Griekse himne (kyk Wünsch 1914; KeyBner 1932; Bremer 1981; Thraede 1993). Dit het dus 'n tipiese driedelige struktuur met 'n aanroep of invokasie (vv.1-6), aretalogie of argument (vv.7-31) en gebed (vv.32-39). Die aanroep bevat kenmerkende elemente soos die opnoem van die god se attribute en epiteta en 'n verwysing na die grondslag vir die verhouding tussen die god en die aanroeper. In die middelgedeelte tref ons lof van die god se mag en regering aan, gevolg deur wat

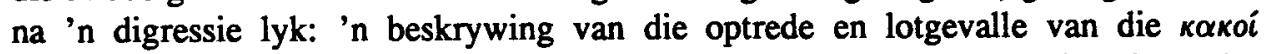
('slegte mense'). Die argument-deel van 'n himne bevat egter dikwels ander elemente behalwe lof om die god welwillend te stem (Wünsch 1914:145). Aan die einde van die gedig het ons weer epiteta en 'n gebed wat opnuut tot die god se lof lei.

Die Himne aan Zeus is natuurlik nie bloot 'n tradisionele himne nie. Die skrywer is trouens die filosoof Kleantes en die Zeus aan wie die himne gerig is, is vir 'n Stoïsyn nie bloot die oppergod van die Griekse panteon nie, maar die aktiewe beginsel in die Stoïsynse sisteem, "the one primary being, who has engendered, and again absorbs into himself, all things and all Gods. He is the universe as a unity, the primary fire, the ether, the spirit of the world, the universal reason, the general law 
or destiny" (Zeller 1880:358; vgl Wilamowitz-Moellendorff 1924:258-59; Mansfeld 1979:129; Steinmetz 1994:571-72, 578). Binne hierdie konteks kan 'n mens verwag dat die himne tot die genre van filosofiese himnes moet behoort (só Renehan 1964:382; Untersteiner 1980:54-57). Sulke himnes word gewoonlik aan personifikasies van onpersoonlike beginsels gerig, of aan tradisionele gode wat as natuurbeginsels geallegoriseer is (Untersteiner 1980:54-57; des Places 1957).

Dit laat die vraag ontstaan of Kleantes se Himne aan Zeus werklik 'n uiting van godsdienstige vroomheid is soos so dikwels gekonstateer word (kyk die indrukwekkende lys van aanhalings in Mansfeld 1979:130-131), of gebruik Kleantes bloot die himniese vorm om sy filosofiese beginsels aantrekliker in te klee (Susemihl 1891:64; Festa [1932-1935] 1971:2.75-77; 1935:169-180)? Anders gestel: is hierdie himne werklik bedoel as 'n gebed aan 'n godheid of is dit slegs 'n uitdrukking van die skrywer se bewondering vir die allesomvattende orde in die natuur? Verskeie geleerdes beweer dat dit onsinnig is vir 'n Stö̈syn om te bid: 'n mens kan nie iets van 'n onpersoonlike natuurlike mag vra nie; 'n mens kan jou hoogstens daaraan onderwerp. 'n Ware godsdienstige gebed hoort nie tuis in die filosofiese raamwerk van die Stoïsisme nie (kyk Wilamowitz-Moellendorff 1925:317, 323, 325; 1924:260-261; Sier 1990:106). In my interpretasie hieronder sal ek op hierdie vraagstuk terugkom.

Oor die presiese Sitz im Leben (d.w.s. die sosiaal-historiese konteks) van die Himne aan Zeus kan ons weereens slegs spekuleer. Wilamowitz (1895:197) meen dit was 'n 'tafelgebed'-die simposium was inderdaad 'n heel gebruiklike geleentheid om himnes te sing (vgl Bremer 1981:207)-maar Festa (1935:174) is van oordeel dat die himne aan die begin van 'n nuwe lesingreeks gesing is. Daar is egter geen historiese of literêre aanduidings hiervoor nie.

\section{Komposisie}

Die Himne aan Zeus is met groot sorg gedig. Ná 'n oorsig van die komposisie sal die belangrikste kenmerke van die komposisie uitgelig word.

\section{Oorsig van die komposisie}

I. Invokasie: Lofprysing 1-6

A. Zeus as heerser $1-2$

1. Epiteta wat sy verhewenheid uitdruk 1-2a

2. Beskrywing van sy regering: met die wet $2 \mathrm{~b}$

B. Toepaslike menslike reaksie: lof $3-6$

1. Reg en plig om Zeus aan te spreek 3

2. Rede: mens se bevoorregte posisie in die natuur 4-5

3. Gevolg: besing Zeus se mag 6

II. Argument: Zeus se regering en mens se weerbarstigheid 7-31

A. Beskrywing van Zeus se regering 7-17

1. Gehoorsaamheid van die natuur $\quad 7-16$ 
a. Geordende beweging van hemel 7-8

b. Zeus se instrument: weerlig 9-11

c. Universele rede deurdring alles 12-13

d. Ewige oppermag van Zeus 14

2. Kontras tussen natuur en mens 15-17

a. Afhanklikheid en getrouheid van natuur 15-16

b. Mens se ongehoorsaamheid 17

B. Zeus skep harmonie uit konflik 18-21

1. orde uit wanorde 18-19

2. eenheid in veelvoud, $\mathrm{d}$ i die universele rede $20-21$

C. Mens se weerbarstigheid 22-31

1. Verwerp die universele rede 22-25

a. Oogmerk: verkryging van die goeie 23

b. Probleem: kan nie God se universele wet insien nie 24

c. Verlore geleentheid: 'n goeie lewe met insig 25

2. Voortdurende strewe na uiteenlopende dinge: 26-31

$\begin{array}{ll}\text { a. Roem } & 27\end{array}$

b. Wins 28

c. Plesier 29

d. Gevolg (konflik): 30-31

(1) mens onderwerp aan uiteenlopende invloede $\quad 30$

(2) resultaat die teenoorgestelde van wat beoog is 31

III. Gebed: Verlossing en insig 32-39

A. Gebed om verlossing $32-35$

1. Epiteta wat Zeus se welwillendheid en mag uitdruk 32

2. Versoek: 33-35

a. Verlos uit onkunde 33-34b

b. Skenk insig 34c-35

(1) grondslag van Zeus se regering $\quad 35$

B. Doel van verlossing en insig 36-39

1. Eer aan Zeus vir eer bewys $\quad 36$

2. Wyse: loof sy werke voortdurend $37 \mathrm{a}$

3. Rede: 37b-39

a. Gepaste plig 37b-38a

b. Hoogste eerbewys om die universele wet te besing $38 \mathrm{~b}-39$

Soos reeds vermeld volg die gedig klaarblyklik die tradisionele driedelige himnestruktuur: Invokasie, Argument (ook aretalogie of pars epica genoem) en Gebed.

In die Invokasie (vv.1-6) vind ons lofprysing van Zeus, heerser van die natuur,

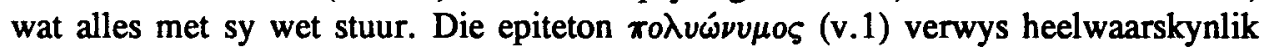
na die Stoïsynse identifikasie van Zeus met die Logos, rede, vuur, noodlot en voorsienigheid (Steinmetz 1994:578). Dit is die mens se reg en plig ( $\theta \dot{\varepsilon} \mu \iota \varsigma$ in v.3 het die dubbele betekenis hier) om Zeus aan te roep en hom te loof. Die rede wat in 
vv.4-5 aangevoer word (ongeag die lesing wat in v. 4 gekies word) ${ }^{6}$ verwys na die bevoorregte posisie van die mens in die natuur en sy besondere verbintenis met god. Indien mens byvoorbeeld Bergk se konserwatiewe emendasie ö $\lambda$ ov $\mu i \mu \eta \mu \alpha$ ("'n afbeelding van die heelal") in v. 4 aanvaar is die besondere posisie van die mens gebaseer op die feit dat hy as mikrokosmos deel het aan die Logos wat alles in die heelal (die makrokosmos) orden. ${ }^{7}$

Die Argument of middeldeel is die mees komplekse van die drie hoofdele waaruit die gedig saamgestel is en dit is moontlik om dit op verskillende wyses onder te verdeel. Die mees waarskynlike indeling is drie onderafdelings: die eerste beskryf Zeus se regering (vv.7-17), die tweede sy vermoë om harmonie, uit konflik te skep (vv.18-21) en die derde die mens se weerbarstigheid (vv.22-31).

In die eerste onderafdeling vind ons 'n beskrywing van die ordelike gehoorsaamheid van die natuur in antwoord op Zeus se leiding: die hemele volg met graagte die aanwysings van sy weerligstraal. ${ }^{8}$ Deur middel van laasgenoemde rig hy ook die universele rede, wat op sy beurt alle dinge, byvoorbeeld die son en die sterre, deurdring en orde skep (vv.7-14). Sowel die weerligstraal as die Logos word op indrukwekkende wyse met epiteta en betreklike bysinne bepaal-as medewerkers van die opperkoning Zeus bied hulle die teenpool vir die slegte mense wat ons later in die gedig aantref.

Die tweede deel van die onderafdeling (vv.15-17) dui die basiese probleem aan wat in die gedig aan die orde gestel word: in teenstelling tot die absolute gehoorsaamheid en afhanklikheid van die natuur is daar slegte mense wat in hul dwaasheid 'sonder Zeus' optree. Dit gee egter aanleiding tot die tweede onderafdeling van die Argument (vv.18-21): Zeus is instaat om orde uit wanorde en eenheid in veelvoud, d.w.s. sy ewige Logos, te skep.

Die finale onderafdeling van die Argument (vv.22-31) beskryf die ongelukkige lot van dwase mense: Aangesien hulle die universele rede, $\mathrm{d}$ w $\mathrm{s}$ die verenigende rasionele orde van die kosmos, vermy, is hulle voortdurend op soek na die goeie, sonder dat hulle raaksien dat 'n goeie lewe juis daarin bestaan wat hulle dwaaslik ontvlug, nl die universele wet. Sonder innerlike orde en dissipline (ă $\nu \varepsilon v$ vóov, v.26;

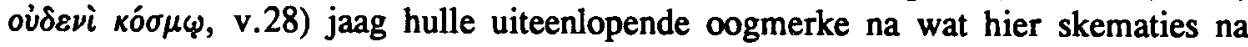

6 Meer is al oor hierdie vers geskryf as oor enige ander deel van die Himne aan Zeus, maar die nimte laat my nie toe om die verskillende konjekture te bespreek nie. Die manuskriplesing is metries onaanvaarbaar; die probleem kan egter opgelos word indien of "̆xov met 'n woord wat 'n kort aanvangsillabe het vervang word, of $\dot{\varepsilon} \sigma \mu \dot{\varepsilon}^{\prime} \nu$ met 'n woord wat 'n elideerbare laaste lettergreep het. In die tekskritiese apparaat is die konjekture aangedui wat na my mening die beste sin maak. Watter lesing 'n mens ookal kies, dit blyk duidelik uit die konteks dat die tweede helfte van v. 4 die basis vir die besondere verhouding tussen god en mens moet aandui.

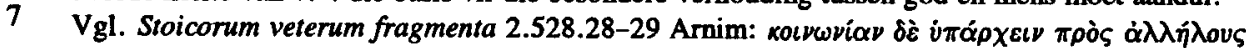

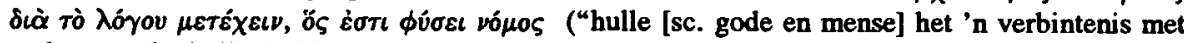
mekaar omdat hulle deel het aan die Logos wat die wet in die natuur is").

8 Die weerlig is heelwaarskynlik simbool van die tóvos ('spanning') wat volgens die Stoïsyne in alle dinge aanwesig is en só bulle grense en innerlike kohesie bepaal. In 'n ander fragment identifiseer Kleantes uitdruklik die weerlig met die tonos (kyk SVF 1.497, 563). 
aanleiding van die drie konvensionele leefwyses (Bio ) geskets word: hulle streef na eer, rykdom en plesier (Wilamowitz-Moellendorff 1913:188-191). Die gevolg is egter dat hulle voortdurend aan uiteenlopende invloede onderworpe is, hoewel hulle daarna strewe dat die geheel en al teenoorgestelde hiervan moet gebeur, $\mathrm{nl}$ om 'n sinvolle lewe te verkry.

In die laaste deel van die Himne aan Zeus, die Gebed (vv.32-39), bid Kleantes dat mense van hulle vernietigende onkunde bevry mag word en dat hulle dieselfde insig mag verkry wzarop Zeus self in sy bestuur van die heelal steun, d.w.s. insig in die universele wet en rede (Logos). Ons sal dan werklik instaat wees om Zeus te loof en te eer vir die eer wat hy aan ons bewys het. Dit is nie slegs ons plig nie; dit is terselfdertyd die hoogste voorreg vir sterflinge sowel as onsterflikes om altyd die universele wet te prys.

Dit is heel duidelik dat motiewe van die Invokasie hier in die Gebed herhaal word, byvoorbeeld die lofprysing van Zeus en sy werke, sy bestuur van die heelal deur middel van die universele wet en die voorreg en plig van mense. Hierdie gebruik van inclusio ('insluiting') aan die begin en einde van Griekse tekste om die afsluiting te markeer en die innerlike kohesie te versterk is natuurlik baie algemeen. Myns insiens het die inclusio egter hier 'n meer beduidende funksie: dit skep die raam waarbinne die inhoud van die Argument-deel verstaan moet word. Hierdie verband sal in meer besonderhede in die volgende en laaste deel van die artikel bespreek word.

Ek wil my bespreking van die komposisie van die Himne aan Zeus afsluit deur te wys op die simmetriese opbou daarvan: Soos sopas vermeld stem die Invokasie (I) tematies met die Gebed (III) ooreen. In die Argument kontrasteer die eerste onderafdeling oor die gehoorsaamheid van die natuur (II.A) met die derde onderafdeling oor die mens se weerbarstigheid (II.C). Dit laat ons met die middelste onderafdeling (II.B) as 'n kern of draaipunt. Dit is voorts merkwaardig dat die korresponderende dele almal min of meer ewe lank is: vergelyk I (6 verse) met III ( 8 verse) en II.A (11 verse) met II.C (10 verse). Daarenteen beslaan die kernonderafdeling II.B slegs 4 verse. Sowel in inhoud as in vorm volg die komposisie dus skematies die volgende patroon: $\alpha \beta \gamma \beta^{\prime} \alpha^{\prime}$. Die simmetriese komposisie help om die sentrale onderafdeling (vv.18-21) te beklemtoon. Soos hieronder duidelik sal blyk word die belangrikheid van hierdie gedeelte ook deur die oorkoepelende betekenis van die gedig bevestig.

\section{Interpretasie}

Die meeste geleerdes beskou die Himne aan Zeus in die algemeen as 'n uitdrukking van bewondering en lof vir die orde in die natuur. So ' $n$ interpretasie is egter nie instaat om twee belangrike dele van die gedig te verdiskonteer nie, nl die beskrywing van die $\alpha \alpha \kappa o i ́$ in vv.17 en 22-31 en die bede in vv.32-35 waarin Zeus gevra word om onkunde te verdryf en insig te skenk.

Kom ons kyk eers na die beskrywing van die какоi. 'n Mens moet daarop let dat, afgesien van v.17, die eerste helfte van die gedig tot en met v.21 uitsluitlik met 
'n beskrywing en lof van Zeus se almagtige regering te make het; ' $n$ mens kan jou maklik ' $n$ hele himne in dié trant voorstel. Sommige geleerdes beskou dus die gedeelte oor die какоi as 'n onnodige digressie. Aangesien die beskrywing van die

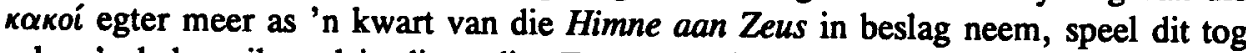
seker 'n belangrike rol in die gedig. Een moontlike oplossing tot die probleem van die funksie van die gedeelte sou wees dat die verwysing na die $k \alpha \kappa o$ as 'n teodisee optree: god se regering is volmaak, maar hy moet verontskuldig word van die kwaad en onvolkomenheid in die wêreld. Die beskrywing van die kakoi dui dus aan wie werklik geblameer moet word vir die kwade, of wat die noodsaaklike funksie van die kwaad in die heelal is (Sier 1990:100). So 'n teodisee sou indirek die god se lof voortsit. Ek vind hierdie verklaring egter onbevredigend, aangesien Zeus nie eksplisiet verontskuldig word nie en daar ook nie 'n eksplisiete rasionalisasie van slegte dade is wat sou duidelik maak dat hierdie gedeelte as teodisee bedoel is nie.

Met die eerste oogopslag sou dit kon lyk of vv.18-21 inderdaad ' $n$ rasionalisasie van die kwaad is: ${ }^{9}$

Maar $u$ weet hoe om die ongelyke gelyk te maak

en om die onordelike te orden; selfs die onbeminlike word deur u bemin.

Want u voeg só alles tot een saam, die goeie met die slegte,

dat daar vir alles één ewigdurende rasionele orde [Logos] tot stand kom.

Twee verskillende argumente vir ' $\mathrm{n}$ teodisee is uit hierdie verse afgelei. In die eerste plek het verskeie geleerdes woordelikse ooreenkomste tussen hierdie verse en fragmente van Herakleitos bemerk (Neustadt 1931:396-397; Zuntz 1958:296-298; Long 1975-1976:143-149). ${ }^{10}$ As agtergrond vir die gedeelte in die Himne aan Zeus

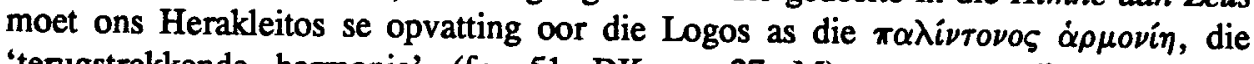
'terugstrekkende harmonie' (fr. $51 \mathrm{DK}=27 \mathrm{M}$ ) verstaan, die coniunctio oppositorum of 'vereniging van teenoorgesteldes' (insluitende die teenoorgesteldes goed en kwaad) waarop die orde in die wêreld gebaseer is. Só gesien is die kwaad 'n wesenlike en noodsaaklike teenpool van die goeie. Volgens hierdie opvatting beteken "selfs die onbeminlike word deur u bemin" (oi $\phi \hat{\lambda} \lambda \alpha$ ooi $\phi \hat{\imath} \lambda \alpha \dot{\varepsilon} \sigma \tau i \nu$ ) in v.19 dat "binne die horison van die coniunctio oppositorum selfs die weerbarstige, negatiewe in die wêreld noodsaaklik en sinvol is" (Sier 1990:104-105).

Indien dit so is, waarom verklaar Kleantes dan in v.17 dat slegte mense 'sonder Zeus' optree en waarom moet Zeus mense van die negatiewe gevolge van hulle dwaasheid red (v.33)? As die goeie en die kwade saam die 'vereniging van teenoorgesteldes', d.w.s. die Logos, vorm, is daar tog sekerlik nie rede vir hierdie implisiete negatiewe beoordeling van die $\kappa \alpha \kappa i \alpha$ nie. Met ander woorde, hoe is die

9 Vgl Sier 1990:100: “Freilich wird in 18-21 erklärt, Zeus habe die Welt so eingerichtet, daß in ihr auch die menschlichen $\alpha \alpha i \alpha$ eine gewisse Funktion erfüllt. Kleanthes macht aber von diesem Argument der Theodizee nur eingeschränkten Gebrauch."

10

Vgl. veral Herakleitos frr. 1 Diels-Kranz $=1$ Marcovich; $2 \mathrm{DK}=23 \mathrm{M} ; 10 \mathrm{DK}=25 \mathrm{M} ; 30$

$\mathrm{DK}=51 \mathrm{M} ; 50 \mathrm{DK}=26 \mathrm{M} ; 102 \mathrm{DK}=91 \mathrm{M}$. 
oënskynlik positiewe beoordeling van die kwaad in vv.18-21 te rym met die negatiewe beoordeling daarvan elders in die gedig?

Sier (1990:105) stel dus tereg voor dat ons afsien van die Heraklitiese interpretasie van vv.18-21. Hyself gee die volgende interpretasie:

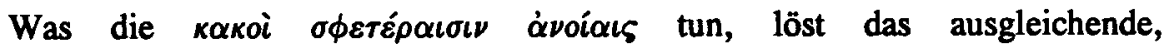
'begradigende' Wirken des Zeus aus, der die Dinge wieder ins Lot bringt und das Verkehrte in geordnete Bahnen zurücklenkt; und was ihm der Qualität nach widersirebt..., gibt ihm doch wilikommene Geiegenheit, die überlegene Organisation seines Kosmos zu beweisen.

Dit is klaarblyklik 'n variasie van die teodisee-verklaring: die kwaad word 'geregverdig' deurdat dit god toelaat om sy oorweldigende goedheid te demonstreer. 'n Mens kan egter weer vra of die kwaad volgens hierdie opvatting nie nog steeds 'n te positiewe rol speel nie. Voordat ons egter die rol van die kakoi in die Himne aan Zeus probeer omskryf, kyk ons eers na die tweede probleem wat hierbo vermeld is, nl. die funksie van die bede aan die einde van die gedig.

Geleerdes het moeite om die gebed in vv.32-35 ernstig op te neem. Hulle argumenteer dat dit sinneloos is om tot die Stoisynse Zeus te bid, wat terseldertyd die immanente Universele Rede, Noodsaak en Voorsienigheid is, én die materiële, kunstige vuur wat alles deurdring, 'n geheel en al onpersoonlike mag. Wat meer is, aangesien alles in die Stoïsynse wêreld bepaal word deur 'n streng kousale opeenvolging van gebeurtenisse wat tot die uiteindelike goed van die heelal as geheel lei, is al wat mense kan doen om hierdie toestand van sake te aanvaar en hul voor die Noodsaak te buig. Vir 'n Stoïsyn kan 'n gebed aan Zeus dus "slegs in 'n onderwerping aan die Noodsaak en 'n onbegrensde bewondering van die ewige alwyse wêreldorde bestaan" (Wilamowitz-Moellendorff 1925:323; vgl. p.325); dit is sinneloos om hom te vra om iets te doen. Volgens Sier $(1990: 106)$ is die bede aan die einde van die gedig "bloot die godsdienstige projeksie van dit wat Zeus as

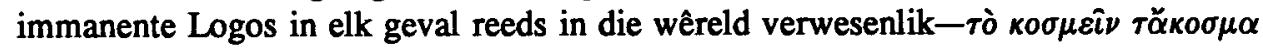
["om die onordelike te orden", v.19]".

Ruimte laat my nie toe om die probleem van die Stoïsynse godsdiens in die algemeen en die Stoïsynse opvatting van gebed in die besonder te bespreek nie. Ek volstaan deur te sê dat in teenstelling met wat 'n mens sou verwag, baie Stoïsyne wel 'n sterk godsdienstige gevoel openbaar en wel gebede uiter wat vir ons opreg voorkom. 11 Ek wil beweer dat wat Kleantes se Himne aan Zeus betref, die bede aan die einde 'n integrale deel van die gedig is en dat die Invokasie- en Argument-dele van die himne op die Gebed afgestem is. 12

11 Kyk Simon 1980 vir 'n sensitiewe bespreking van die probleem. Mansfeld (1979:129-136) bespreek kortliks die probleem van Stoïsynse godsdiens.

12 Hierdie verhouding is normaal in tradisionele himnes; kyk Wünsch 1914:145. James (1972:38) beskou ook die gebed as "the climax of the poem". 
Heel opmerklik in die Gebed-deel is die nadruk op en die toepassing van die beginsel van wederkerigheid tussen god en mens. ${ }^{13}$ Zeus word gevra om $\gamma \nu \dot{\omega} \mu \eta$, 'insig', sodat ons hom en sy werke kan eer en prys. Hierdie insig is egter een en dieselfde waarop Zeus se eie regering gebaseer is (vv.34-35)-met ander woorde,

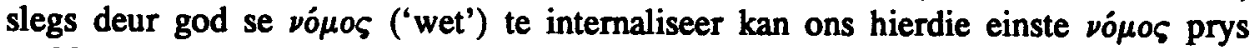
(v.39). Hierdie verband word tekstueel onderstreep deurdat $\delta i \kappa \eta$, 'geregtigheid', sowel gebruik word om god se regering (v.35) as ons lof van sy wet (v.39) te omskryf. Ons moet dieselfde 'geregtigheid' aan Zeus bewys as wat hy in sy bestuur van die wêreld beoefen. Zeus se gawe van insig word verder beskryf as 'n eer waarop ons moet reageer deur Zeus op ons beurt te eer $(\tau \mu \mu \eta \theta \dot{\varepsilon} \nu \tau \varepsilon \varsigma \dot{\alpha} \mu \varepsilon i \beta \dot{\omega} \mu \varepsilon \sigma \theta \dot{\alpha} \sigma \varepsilon$

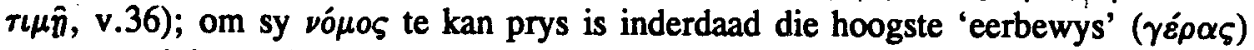
wat aan enigiemand gegee kan word (vv.38-39).

Dieselfde beginsel van wederkerigheid is ook in die Invokasie aan die werk: op grond van ons bevoorregte posisie as mense kan ons Zeus aanspreek, maar het ons ook die plig om sy regering te prys. Om Zeus te prys is as ' $t$ ware ' $n$ natuurlike gevolg $(\tau \hat{\varphi}, v .6)$ van die bevoorregte posisie wat mense binne Zeus se wêreldorde beklee.

As mens na die Argument-deel kyk, bemerk mens aanvanklik dieselfde wederkerige verhouding: die hele kosmos reageer op Zeus se regering met gewillige gehoorsaamheid (vv.7-8); sy ordelike en doeltreffende regering word gebalanseer deur die orde wat dwarsdeur die natuur openbaar word (vv.7-16). In die geval van 'slegte mense' word hierdie verhouding egter deurbreek (v.17). Instede daarvan om

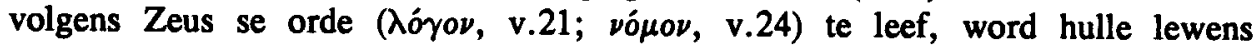
versplinter deurdat hulle uiteenlopende doelwitte najaag; instede van die ev̌poı $\alpha$ Biov, die 'ordelike lewensvloei' wat die Stoïsynse ideaal is, lei hulle lewens tot onrus, sonder om die goeie dinge te bereik waarna hulle strewe (vv.22-31).14 Instede van orde en eenheid vertoon hulle lewens wanorde en fragmentering.

Teen hierdie agtergrond behoort dit duidelik te word dat die bede aan die einde nie slegs 'n nagedagte is nie, maar inteendeel dit waarna die hele komposisie opwerk en wat die verskillende onderdele van die Argument integreer. Deur te bid dat die какoi gered moet word van hulle onkunde (v.33) en insig moet verkry sodat ons almal god se orde kan besing, versoek Kleantes inderdaad dat hulle in hierdie orde geherintegreer moet word. Die beskrywing van die gehoorsaamheid en orde van die

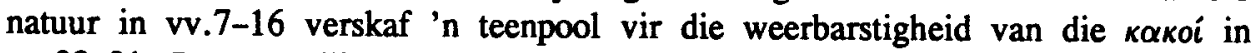
vv.22-31. In teenstelling met die gehoorsaamheid van die natuur weerstaan hulle god se regering. Vv.18-21 fungeer as 'n skarnier tussen hierdie twee gedeeltes (Sier 1990:102-103). Dit vorm 'n oorgang vanaf die orde van die natuur tot die wanorde

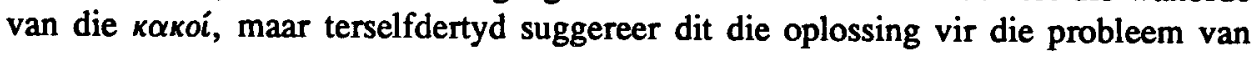

13 Dis 'n algemene motief in Griekse himnes; kyk KeyBner 1932:134. Die wesenlike rol van reprositeit vir die verstaan van die Himne aan Zeus word beklemtoon deur Festugière ([1949] 1983:310-332).

14 Vgl. Zuntz 1958:307. દข̌ Kleantes and Chrusippos) vind ons in SVF 1.184, 554; kyk ook Steinmetz 1994:574. 


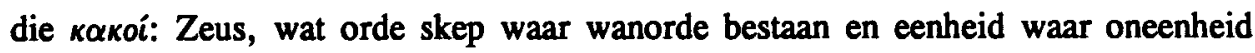
bestaan, sal ook instaat wees om die kakoi te herintegreer. 'n Mens moet dus vv.1821 in 'n teleologiese sin verstaan. Ons kom tot die slotsom dat die hele gedig rondom die probleem van die 'slegte mense' draai wat Zeus se orde ignoreer.

As dit inderdaad die betekenis van die gedig is, moet die gebed klaarblyklik met erns bejeën word: Kleantes versoek Zeus om 'n brug te slaan tussen die werklikheid

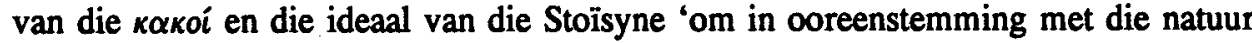

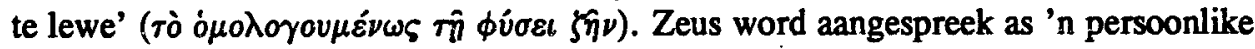
mag wat instaat is om onkunde en wanorde in lof te omskep.

Daar is egter een verdere aspek van die gebed waarop ons moet let: ná sy beskrywing van die bejammerenswaardige toestand van die 'slegte mense' (vv.2232), vra die digter Zeus om die mensdom ( $\dot{\alpha} \nu \rho \rho \dot{\omega} \pi 0 v_{\varsigma}, v .33$ ) van hul onkunde te red, sodat ons ( $\dot{\alpha} \mu \varepsilon \iota \beta \dot{\omega} \mu \varepsilon \sigma \theta \alpha, v .36)$ sy werke kan loof. In hierdie klimaktiese opeenvolging word die digter en sy metgeselle geidentifiseer met die какоі-alle mense is terselfdertyd bevoorreg weens hulle verbintenis met god (v.4) én het behoefte aan sy hulp. Benewens lof en gebed is Kleantes se Himne aan Zeus ook 'n belydenis van die mens se behoefte aan god om die kwaad te ontkom.

\section{BIBLIOGRAFIE}

Adam, J 1911. The Vitality of Platonism and Other Essays. Ed. A M Adam. Cambridge: Cambridge University Press.

Bremer, J M 1981. Greek Hymns. In Versnel, H S (ed.), Faith, Hope and Worship: Aspects of Religious Mentality in the Ancient World, 193-215. Leiden: Brill. (Studies in Greek and Roman Religion 2.)

Festa, N [1932-1935] 1971. I frammenti degli stoici antichi. 2 vols. Hildesheim: Olms. (Filosofi antichi e medievali.)

Festa, N 1935. Ortodossia e propaganda nello stoicismo antico. In: Mélanges offerts à M. Octave Navarre par ses élèves et ses amis, 169-180. Toulouse: Privat.

Festugière, A-J [1949] 1983. La révélation d'Hermès Trismégiste. Vol. 2. Le dieu cosmique. Paris: Les Belles Lettres. (Collections d'études anciennes: Études bibliques.)

Festugière, A-J 1954. Personal Religion among the Greeks. Berkeley \& Los Angeles: University of California Press. (Sather lectures.)

Hopkinson, N (ed.) 1988. A Hellenistic Anthology. Cambridge: Cambridge University Press. (Cambridge Greek and Latin Classics.)

James, A W 1972. The Zeus Hymns of Cleanthes and Aratus. Antichthon 6, 28-38.

KeyBner, K 1932. Gottesvorstellung und Lebensauffassung im griechischen Hymnus. Stuttgart: Kohlhammer. (Würzburger Studien zur Altertumswissenschaft 2.)

Long, A A 1975-1976. Heraclitus and Stoicism. Philosophia 5-6, 133-156.

Mansfeld, J 1979. Providence and the Destruction of the Universe in Early Stoic Thought: With Some Remarks on the 'Mysteries of Philosophy'. In: Vermaseren, M J (ed.), Studies in Hellenistic Religions, 129-188. Leiden: Brill. (EPRO 78.) 
Meerwaldt, J D 1951. Cleanthea I. Mnemosyne 4, 40-69.

Meerwaldt, J D 1952. Cleanthea II. Mnemosyne 5, 1-12.

Meijer, P A 1983. Kleanthes' Loflied op Zeus: Kunt ge nog zingen, zing dan mee! Lampas 16, 16-37.

Neustadt, E 1931. Der Zeushymnos des Kleanthes. Hermes 66, 387-401.

Places, É des 1957. Hymnes grecs au seuil de l'ère chrétienne. Biblica 38, 113-129. Pohlenz, M 1940. Kleanthes' Zeushymnus. Hermes 75, 117-123.

Renehan, R 1964. The Collectanea Alexandrina: Selected Passages. Harvard Studies in Classical Philology 68, 375-388.

Sier, K 1990. Zum Zeushymnos des Kleanthes. In Steinmetz, P (Hrsg.), Beiträge zur hellenistischen Literatur und ihrer Rezeption in Rom, 93-108. Stuttgart: Steiner. (Palingenesia 28.)

Simon, M 1980. Prière du philosophe et prière chrétienne. In: Limet, H \& Ries, J (éds.), L'expérience de la prière dans les grandes religions: Actes du Colloque de Louvain-la-Neuve et Liège (22-23 Novembre 1978), 205-224. Louvain-laNeuve: Centre d'histoire des religions. (Homus religiosus 5.)

Steinmetz, P 1994. Die Stoa. In: Flashar, H (Hrsg.), Grundriss der Geschichte der Philosophie: Die Philosophie der Antike. Bd. 4.2. Die hellenistische Philosophie, 491-716. Basel: Schwabe.

Susemihl, F 1891. Geschichte der griechischen Literatur in der Alexandrinerzeit. 1. Bd. Leipzig: Teubner.

Thraede, K 1993. Hymnus I. Reallexikon für Antike und Christentum 16, 915-946.

Untersteiner, M 1980. Problemi di filologia filosofica. Ed. L Sichirollo \& M Venturi Ferriolo. Milano: Cisalpino-Goliardica.

Verbeke, G 1949. Kleanthes van Assos. Verhandelingen van de Koninklijke Vlaamse Academie voor Wetenschappen, Letteren en Schone Kunsten van België, Klasse der Letteren 11/9. Brussel.

Watanabe, A T 1988. Cleanthes, Fragments: Text and Commentary. Unpublished $\mathrm{Ph} . \mathrm{D}$. dissertation, University of Illinois at Urbana-Champaign.

Wilamowitz-Moellendorff, U von 1895. Aratos von Kos. In: Nachrichten von der Königlichen Gesellschaft der Wissenschaften zu Göttingen, Philologischhistorische Klasse aus dem Jahre 1894, 182-199. Göttingen: Commissionsverlag der Dieterich'schen Verlagsbuchhandlung.

Wilamowitz-Moellendorff, U von 1912. Die griechische Literatur des Altertums. In: Wilamowitz-Moellendorff, U von et al., Die griechische und lateinische Literatur und Sprache, 3-318. 3. Aufl. Leipzig \& Berlin: Teubner. (Die Kultur der Gegenwart 1/8.)

Wilamowitz-Moellendorff, U von 1913. Sappho und Simonides: Untersuchungen aber griechische Lyriker. Berlin: Weidmannsche Buchhandlung.

Wilamowitz-Moellendorff, $U$ von 1924. Kleanthes Zeushymnus. In: idem, Hellenistische Dichtung in der Zeit des Kallimachos, 2. Bd., 257-261, 324-325. Berlin: Weidmannsche Buchhandlung.

Wilamowitz-Moellendorff, $U$ von 1925 . Kleanthes. Hymnus auf Zeus. In: idem, Reden und Vorträge, 1. Bd., 306-332. 4. Aufl. Berlin: Weidmannsche Buchhandlung. 
Wilamowitz-Moellendorff, U von 1955. Der Glaube der Hellenen. 2 Bde. 2. Aufl. Darmstadt: Wissenschaftliche Buchgesellschaft.

Wünsch, R 1914. Hymnos. Paulys Realencyclopädie der classischen Altertumswissenschaft $9.1,140-183$.

Zeller, E 1880 . The Stoics, Epicureans and Sceptics. New \& revised ed. by O J Reichel. London: Longmans, Green, \& Co.

Zuntz, G 1958. Zum Kleanthes-Hymnus. Harvard Studies in Classical Philology 63, 289-308. 